\title{
The Psalter in the Canon
}

\author{
Knud Jeppesen ${ }^{1}$ \\ Vice-Rector: Tantur Ecumenical Institute for Theological Studies \\ (Jerusalem, Israel) \\ Research Associate: University of Pretoria
}

\begin{abstract}
The Psalter, read as a coherent book instead of being read as 150 independent poems, reveals some patterns and a continuum of ideas, which might not express the editors' original intention, but support the readers' understanding of this canonical book. The article suggests that, even if the majority of texts are laments, the Psalter is a book of praise, underlined for instance by the endings of the Psalter's five books. The five books relate the Psalter to the Pentateuch, and a form of competition between David and Moses is found (see esp Book 4), of which David was the winner. This is one of the reasons why the Christians were able to read the Psalter as a Christian book.
\end{abstract}

\section{HOLISTIC READING}

In recent research it has become more common to read the Old Testament texts in the context of the entire Bible than when the author and Dr Steingrimsson, who is honoured in this article, went to university. I first met him during a study trip to Uppsala, some thirty years ago. Dealing with the subject of the Psalms in those days, we were taught to regard the single Psalm almost as a self-contained entity, with the preceding and subsequent Psalms not very often used to widen our understanding. For example, by reading the David-psalm, Ps 3: "O Lord, how

\footnotetext{
${ }^{1}$ Prof Dr Knud Jeppesen, Emeritus Professor at Aarhus University (Denmark), is a member of the International Advisory Board of Hervormde Teologiese Studies. Prof Jeppesen participates as associate in the research project "Biblical theology and Hermeneutics", directed by Prof Dr Andries G van Aarde, Department of New Testament Studies, Faculty of Theology, University of Pretoria. Prof Van Aarde visited the Tantur Institute in Jerusalem in March 2003. Some of the ideas presented in this essay will be published in Danish in a three volume Psalm Commentary, edited by E K Holt and K Nielsen (2002). See especially Vol 1, ch 2 and 7, and in Vol 2 and 3 the commentaries to the psalms dealt with here. The article will also be published in a forthcoming Festschrift dedicated to Dr Sigurdur Örn Steingrimsson, Reykjavic, Iceland.
} 
many are my foes!"2 ( $v 2$ ), it would normally not form part of the exegesis to ask if the fact that the previous Psalm is about Yahweh and his Messiah and describes their power in the world, and how their enemies were defeated, is of any significance; nor was it a routine question to enquire whether the final words of the prayer Ps 4, "O Lord, make me lie down in safety" ( $v$ 9), have any connection with the end of Ps 3: "Deliverance belongs to the Lord, may your blessing be on your people" ( $v$ 9)!

It is of course well-known that in the Hebrew Bible the book of Job follows the Psalter, and that in for example the Luther Bible, the order is the opposite, but the question whether this difference could have any influence on the understanding of the two books, was hardly asked. In recent literature problems such as these have been discussed at some length and the new trend, sometimes called holistic ${ }^{3}$ reading, has proved to be of significance for the understanding of the single Psalm. Nowadays, there is much more room than before for a reading of the Psalter as one entity ${ }^{4}$ and to discuss its place in Canon.

Traditionally, when scholars relate a Psalm under investigation to other Psalms, the reason would be that the other Psalms belong to the same Gattung as the text in question or that they can be fitted into a common cultic pattern. ${ }^{5}$

\footnotetext{
${ }^{2}$ In most cases the translation used is The New Revised Standard Version: The New Oxford Annotated Bible (1994); however, the numbering of the verses in Biblia Hebraica is followed.

${ }^{3}$ I could also have used the label canonical reading, as it has been used by B S Childs 1979 and other works; Childs' ideas have also been an inspiration, but it has become increasingly clear to me that the word Canon is not as unambiguous as was often thought. It is sometimes difficult to establish whether a scholar uses the term the Old Testament canon about the Hebrew Bible or an Old Testament from the Christian traditions with its different order of books. In this article canon is used to refer to the totality of books of which the Bible in its different forms is made up. In a sense canon used in this way can include the Hebrew Bible, the Septuagint, the Vulgate, the Luther Bible, King James Version etc.
}

${ }^{4}$ It is not the intention of this essay to discuss this trend in much detail, but to present some ideas inspired by it. The literature is already overwhelming, so I restrict myself to mentioning only a few of the works, which have been of importance for my own research: Koch (1994); McCann (ed) (1993); Millard (1994); Whybray (1996); Wilson (1985).

${ }^{5}$ Westermann (1964:344) puts it as follows: "Der Zusammenhang eines Psalms ist seine Gattung, die auf den Ort und den Sinn dieser bestimmten Gruppe von Gebeten im Ganzen des Redens zu Gott weist." According to Mowinckel (1962:1.30, 32, and 33), "the Psalms are - with very few exceptions - real cult psalms, made for cultic use" and that "will in many cases mean that they belong to some definite cultic 'festival' .... In other words ... the pure 'examination of types' ... has to be enlarged and replaced by proper cult-historical ones." 
The latter method was taught by Mowinckel in Scandinavia from 1922 onwards and was further developed by members of the so-called Uppsala-school. It has its origin in the form-critical approach, mainly developed by Gunkel (1924) in his commentary on the Psalms commentary and especially in his introduction to the Psalms (Gunkel \& Begrich 1933). A clear impression that emerges from reading contemporary scholarly literature on the field of Psalm exegesis is that the aftereffect of the form-critical school will last longer than that of the cultic interpretation; although to a large extent exegesis still begins with decisions about Gattung and Sitz im Leben and that is most likely to be the case for many years to come.

The results of the form-critical method are much easier to cross-examine and control, than what a holistic reading can produce. We don't know and probably never will know whether the canonical order of the Psalms follow a thought-through plan; on the other hand, the present form and order is a historical fact we can relate to, and when the Psalms are read in a canonical order, different lines of ideas seem to be revealed. But it is necessary to stress again and again that it should not be claimed that the holistic reading represents with any measure of doubt an original intention, and furthermore, it should be borne in mind that the lines of thoughts found, might not be the only possible lines. However, studying some of the new methods has convinced the writer that through the cautious use thereof, it is possible to obtain new knowledge about the Psalter and to also make adjustments to results achieved by for example the form-critical researchers.

\section{THE PSALTER IN THE HEBREW BIBLE}

Reading Gunkel the impression is created that the Psalter, for the greater part, is a source book for people who want to express feelings of lament; the individual laments are "(der) eigentliche() Grundstock des Psalters" "und auch die Frömmigkeit des Volkes hat hier Anleihen gemacht" (Gunkel-Begrich 1973:173). There is no reason to question such statements, but on the other hand, when if you the entire psalter is read in its Hebrew, canonical form, it becomes clear that it is a collection of poems aimed at praising God. 
It is a well known fact that David's psalms, like the Moses-literature, are divided into five books (cf Midrash Tehillim to Ps 1), a matter regarded as not being of great importance by the historical critical schools. But this division deals with the final composition of the Psalter and must therefore be of some consequence for the understanding of this biblical book. A doxology is found at the end of each of the first four of these books (Ps 41:14; 72:18-19; 89:53; 106:48). The shortest of these appears at the end of the third book (Ps 89:53) and begins with a formula of praise, "blessed be" (ברוך), without specifying who is to be blessed. Then follows the name of God, Yahweh, as the object for blessed, and a short statement that the praise will be eternal. The doxology ends with a double Amen, but we are not told by whom the Amen is proclaimed. The same four elements with some variation appear in the three other doxologies, but only in the last one is it stated that the Amen is proclaimed by the people (בלהעם; Ps 106, 48).

The fifth book does not conclude with a doxology of the same type, but Ps 145 develops in extended form themes from the four doxologies; in this Psalm the Psalter's last examples of the Hebrew verb for bless (ברך), known from the doxologies, are found to express human beings' praise of God or his name $(145: 1,2,10,21)$. Furthermore, in the last line of the Psalm the subject of the blessing of God's holy name forever and ever is extended from the people (Ps 106:48) to all people, all flesh (בלבשר; Ps145:21). The praise of God is or will become universal!

In Ps 145:2 the root ברך is used in parallel to another word for praising God, הלל . This verb on the other hand dominates Ps 146-150; almost half of the appearances of הלל in the Psalter are found in the last five Psalms, especially concentrated in Ps 148:1-4 and 150, and in this last Psalm the verb appears thirteen times in six verses. Of course, in several cases the plural imperative is part of the formula hallelu-jah, often kept as a loanword in the Bible translations.

In the Hebrew Bible the fourth book in the Psalter ends with a hallelujah (Ps 106:48); ${ }^{6}$ which is only the fourth occurrence thereof in the Psalter, the first

\footnotetext{
${ }^{6}$ In the Septuagint, often followed by western Christian Bible translations, this hallelujah is moved to the first verse of Ps 107, i e at the beginning of the fifth book. This is not the only case, where a hallelujah found at the end of one psalm in the Hebrew text is placed at the beginning of the next in the Septuagint. It seems as if in a way, the hallelujah was not considered as part of the psalm proper, but was used to link the psalms in question together.
} 
three being Ps 104:35; 105:45; 106:1, which in other words means that no "hallelujah" appears in the first three books of the Psalter. ${ }^{7}$ The other occurrences, about twenty of them, all appear in the fifth book as part of an effort to let the Psalter end on a note of praise to God and in this way to reflect the Psalter's Hebrew name תהלים.

The Old Testament narratives deal with what God has done for his people, while the Law and the Prophets deal with what he has said to them. The Psalms represent reactions to these matters and sometimes people's reflection and meditation on those matters; in times of distress and disaster they lament and pray to the God described in the other books, and in times of joy, they bless and praise him (cf Von Rad 1969:366). ${ }^{8}$ But reading through the Psalter, the importance of praising him is stressed more and more. The congregation which praises God, would normally consist of "all his faithful ... the people of Israel who are close to him" (Ps 148:14). The second last Psalm, Ps 149, is "a new song", dealing with Israel and its happy relation to its maker and king (v 1-2). By means of the repeated use of $h a l^{e} / \hat{u}$, Ps 150 continues with an extensive call to a song of praise for God's mighty deeds, inviting the congregation to play all kinds of musical instruments. However, in the last line of Ps 150, it is revealed that the congregation now consists of הנשמה. Traditionally, this line is translated as "Let everything which breathes praise the Lord!" and it is, admittedly, a wonderful thought to have the Psalter end with the idea that all living creatures should partake in the song of praise. I In most cases in the Old Testament נשמה is however used in relation to human beings - if not to God himself ${ }^{9}$ - and therefore it might be better to translate it as "Let everyone who breathes praise the Lord!" and thus have the Psalter proclaim that all humanity of all nations should take part in the universal praise as anticipated in Ps 145:21.

\footnotetext{
${ }^{7}$ In Psalms 1-89 the verb הלל is found about fifteen times.

${ }^{8}$ In a parenthesis to the heading "Israel vor Jahwe" Von Rad refers to the part of his Theologie 1 which deals with the Psalms as "Die Antwort Israels".

${ }^{9}$ The only case where גשמה might be used in a designation for all living creatures is in Gen 7:22 (see also the title of Jeppesen 1998, "Alle der ånder skal lovprise Herren")!
} 
From the beginning of the Psalter it is obvious that a Psalm can reflect other parts of the Bible. Just as the order of the Psalms appears to be of some significance, so too might the position of the Psalter in relation to the other biblical books also be of significance. However, the books in the Hebrew Bible and in the Old Testament have not always been in a fixed order. It is a relatively modern phenomenon that the books follow a specific order which, whether intentionally or not, defines the canonical context of each book. Insofar as the Hebrew bible consisted of scrolls of more or less independent books, the order was probably not of decisive importance.

The theological and literary structures of the books, as well as the supposed age of the books were probably of relevance when at some stage of the Bible's history, it was decided, which of the books were to be considered as holy, and in which of the three sections, into which the Hebrew biblical books have been divided way back in history, at least before the New Testament was finished, they belonged. ${ }^{10}$

The order of the books as it appeared in the three parts became of significance when the content was written on sheets, and the sheets were collated and bound together. Yet, much deliberation and controversy followed before the Jewish Hebrew Bible and the Christian Old Testament found the form or rather the forms that we today consider almost unfailing.

As far back as tradition can be traced, the books of Moses have always been the first five of the biblical books, both in the Hebrew Bible, for which only the Jews were responsible, as well as in the Greek translations, which the Christians eventually took over and made their Bible (see, e g, Müller 1996). ${ }^{11}$ Furthermore, it seems to have been taken for granted early in both the Jewish and the Christian tradition that the historical narrative, which ideologically is

\footnotetext{
${ }^{10}$ See the prologue to Sirach and (cf Lk 24:44) where the third part is called the Psalms. But of course, it is one thing that the three parts could already been established, but another what they consisted of at the time of Sirach or Luke.

${ }^{11}$ Regarding the order of the Old Testament, see Beckwith (1985:181-234).
} 
related to Deuteronomy, was placed immediately after the books of Moses and its books placed almost always in the order, we know today. But, after the long history narrative, ending in 2 Kings, the order of the books was variable; in some cases chronological and in other cases literary considerations seem to have played a role in the placement of a single book.

The Psalter is most often mentioned in conjunction with wisdom books like Proverbs and Job in Jewish sources or by church fathers, where the Hebrew or Old Testament holy books are listed. This means that the Psalter has, so to speak, always been canonical. But it is impossible to establish when the Psalter got its present form and content. There are differences between the Hebrew and the Greek Psalter (see below), and some of the old translations, for example the Syrian translation, have more than 150 Psalms. Consequently, the appearance of the title the Book of Psalms in a list does not prove that this is exactly the same collection of Psalms as we find in a Hebrew or a Christian Bible today.

\section{MOSAIC OR DAVIDIC?}

We don't know for sure at what stage the Hebrew Bible was composed of the same number of Books and in the same order as are found in modern printed editions. ${ }^{12}$ But, as already mentioned, early in history, the books were divided in the three parts, the Law, the Prophets and the Writings. When we read those today we find features which link the parts together. For example, it is easy to perceive a link between the end of Deuteronomy and the beginning of the book of Joshua, or should we say the end of the Law and beginning of the Prophets, namely Moses and the Torah. ${ }^{13}$ And again at the end of the Prophets Moses and

\footnotetext{
12 In a way the discussion about the order of the books continues to the present day. Biblia Hebraica Stuttgartensia (Stuttgart 1967ff) is a printed edition of Codex Leningradensis from the $10^{\text {th }}$ century CE, but in the preface the editors state without any commentary that the books of Chronicles are placed as the last books in $B H S$, although they appear earlier in the Codex (see BHS, editior minor 1984, XI).

${ }^{13}$ Moses' prophetical deeds are said to be unique, but still his work was continued through his heir Joshua; Deut 34:9-12 being closely connected to Jos 1:1-9.
} 
the Torah are mentioned, in this instance related to another prophet, Elijah (Mal 3:22-26).

The Psalter is most often listed as the first book of the Writings, followed by Job and other wisdom books, ${ }^{14}$ and the word torah (cf Mal 3:22) occurs twice in vs 2 of the first Psalm. However, the connection between the Prophets and the Psalter is not as marked as the connection between Deuteronomy and the book of Joshua, but the presence of the word, torah, still gives the Psalter a kind of mosaic authority. The word torah does not often appear in the Psalter, as it is, it is only found in nine Psalms. ${ }^{15}$ Although there are connections between some of the nine, for example between Ps 1:1-2 to Ps 40:5 and 94:12 and especially with regard to Ps 19 and 119, it cannot be claimed that the "torah-psalms" make up a special group of Psalms. The word torah is scattered over the larger part of the Psalter and in this way it again and again reminds the reader of the line from the Psalms back to the books of Moses.

It has long been recognised that Ps 1 and 2 together form a kind of introduction or prologue to the Psalter, although scholars have treated this insight differently (e.g., Miller 1993 and Carlson 2000). In contrast to most Psalms in the first book of the Psalter, the first two do not have headings, and even in the Septuagint this is the case with most of the Psalms having headings. Consequently, it appears as if from the beginning, the two Psalms, being as they are framed by two sentences, each introduced by the word "אשד, "happy are", have been considered as special.

A comparison between the relation Ps 1 - Ps 2 and the relation Gen 1 Gen 2-3 reveals a touch of similarity in the structures of the beginning of the five books of Moses and the five books of Psalms, the "books of David", a similarity which I, however, don't want to stress too much. As is well known, Gen 1 and 2-3 are different in their dealing with the creation of the world. Gen 1 reveals a world

\footnotetext{
${ }^{14}$ The wisdom literature is the least specific Israelite and the most universal genre in the Old Testament. As such, it provides an excellent follow up to the "international" note on which the Psalter ends (see above). Regarding the order of the books, see again Beckwith (1985).

${ }^{15}$ Ps 1 (two times), 19, 37, 40, 78 (three times), 89, 94, 105, and 119 (31 times). The weight of the many appearances in Ps 119 is in a way supportive of the theory that Ps 1 and 119 are the frame around an earlier collection of Psalms (Westermann [1962] 1964:338).
} 
of order, and the way of life in this world is clear and measurable. Time structures the order of life; human beings have Lebensraum and enough food, even though they have to share it with other living creatures. Therefore, by the end of the first chapter in the Bible, God was able to state that everything was very good (Gen 1:31).

The world according to Gen 2-3 is and becomes far more complicated; from the beginning, God took the Adam, whom he had created, and placed him in a garden which he had to till and keep a situation which in a way was without problems. But then later on a revolt took place against God and one of the results was a difference in rank among the created beings; bread had to be provided for in the sweat of Adam's face. Fight and death now became possibilities in the world, and it became necessary to have offspring, but even there pain was introduced. By the end of the narrative Adam and Eve could not live the quiet and simple life they enjoyed in the beginning.

Ps 1 and 2 deal with the conditions of life. In Ps 1, life is clear and measurable; the fate of the sinner is bad, whereas the just has fortune on his side. It is a message for ordinary human beings which tells them how to behave in order to sustain the world as good or may be even as very good. Ps 2 is royalistic and develops ideas about the divine king and his power. Human beings no longer are equal; the Psalm deals with a chosen person to whom Yahweh gives promises in order to uphold the good world. Life is complicated and revolts take place; therefore it is necessary for God to have a deputy to rule and punish those people who threaten the balance.

In this way, the literature connected to the names of the two most outstanding figures in the Old Testament literature, Moses and David are related to each other; but in itself, this relation does not tell very much. Only when it is connected to a much more important point, namely that of the role of Moses in the fourth book, can one refer to a secured canonical Moses-David relation in the Psalter. ${ }^{16}$

\footnotetext{
${ }^{16}$ Outside the fourth book of the Psalter, Moses is only mentioned by name in Ps 77:21 (see also Jeppesen 1998).
} 
In the last Psalm (Ps 72) of the second book in the Psalter, the promises given to the king in Ps 2 are confirmed, and again in the first part of the last Psalm in the third book, those promises are repeated and developed (89:2-38). The kingdom and what it implies "shall be established for ever like the moon, an enduring witness in the skies" ( $v$ 38). But immediately following upon these words, the text's mood changes, and the psalmist reproaches Yahweh: "you have spurned and rejected him; you are full of wrath against your anointed" (v 39). This tone of talking to God about his treatment of the king continues throughout the rest of the Psalm ( $v$ 39-52) up to the doxology, which concludes the third book ( $v$ $53)$; but this is of course not part of the Psalm proper.

Several scholars have, with different emphasis, recognised that the transition from Ps 89 to 90, or from the third to the fourth book of the Psalter implies a difference; the general mood is optimistic and it is clear that the atmosphere in the fourth and not least the fifth book is different from that in the last part of Ps 89. There are still some Psalms of the genre, which Gunkel categorized as "Klagelieder der Einzelnen" (Gunkel \& Begrich 933:172), especially those four towards the end of the Psalter (Ps 140-141), followed by a "Bittgebet des Königs" (Kraus 1960:940), which ends by pointing back to Ps 1-2 in the sentence: "happy (אשדר) are the people, whose God is Yahweh!" In short, the fourth and the fifth book of the Psalter can be understood as an answer to the crises with which the first three books end up (see, e g, Westermann [1962] 1964:284; Wilson 1985:214-215; McCann 1993:94; Howard 1993:110). As suggested, one does get the impression that the David-Moses relation is a key issue in this context. It is not unfamiliar to the Old Testament that if a chosen person or institution had failed, God may send a substitute as prophet or servant of the Lord for instance in Isaiah 40-55. In the fourth book of the Psalter such a function was bestowed on Moses. At that stage, the king and the kingdom were not functioning and there was therefore no point in appealing to them to solve any crisis. For this, one has to go back to the most important person in history predating the introduction of the divine kingdom. This person, the Man of God, 
Moses says a prayer in the first Psalm in the fourth book, Ps 90, and we meet him again interceding for the people near the end of the same book in Ps $106 .{ }^{17}$

In the fourth book of the Psalter Moses is mentioned together with Aaron and Samuel as someone who appealed to Yahweh and got an answer (Ps 99:6); later on God is praised for showing mercy and justice by giving Moses knowledge about his "ways" (Ps 103:7), and it is remembered that Moses, together with Aaron were the tools of salvation by leading the people out of Egypt (Ps 105:26). These quotations show that in a critical situation, God is able and willing to send a person such as Moses to help alleviate a situation, and the fourth book will probably conceive such hope again. By using the stories from the holy history in this way, the prayers of Moses indirectly become a promise from God to the people about salvation. After the rejection of the king, the people needed the same kind of intercession, because it implies a positive answer. In Ps 89:51 the king appealed to God, using the imperative "Remember! (זכד)". The people needed to know that a positive answer to this prayer was still a possibility. ${ }^{18}$

The Moses theme culminates in Ps 106. This Psalm lists the people's revolts against God in its early history, when Moses was the leader. He himself fulfils more than one role in the Psalm, ${ }^{19}$ but in our case the most important part of the text is the reconstruction of the, to the people not so flattering story about the golden calf (cf Ex 32). God told Moses that he planned to destroy the people, because they had once again forsaken him. But Moses, whom God entrusted with the role of leader of a new chosen people, instead interceded for the old and crisis struck people. In response to the prayer of Moses, God changed his mind and once again saved them (Ps 106:19-23).

\footnotetext{
${ }^{17}$ In a way the importance of this is underlined by the fact that Ps 90 is the only Psalm in the Psalter which is ascribed to Moses; but it is not the only case in the Old Testament where Moses intercedes for the people (see Aurelius 1988:209 who mentions these examples from the Psalter).

${ }^{18}$ It is therefore significant that God again "remembered"(זכד) in the comforting ending of Ps 106; see $v$ 45. It is not the rejected covenant with David (cf Ps 89:40), which is remembered here, but the covenant with the people. I cannot go into a further discussion about this here, but suffice to mention that as the kingdom of Yahweh is a condition for the kingdom of David, Yahweh's covenant with David does not give meaning without the covenant with the people.

${ }^{19}$ In v 16 Moses is again mentioned together with Aaron, but this time there was conflict between the two leaders and the people.
} 
It has been suggested that the use of the Moses figure, together with the presence of the collection of Yahweh-King hymns (Ps 93; 95-100) ${ }^{20}$ in the fourth book of the Psalter reveals an opposition against the Davidic monarchy; in this regard the word antidavidisch has even been used (Koch 1994:262) ${ }^{21}$ If the herein suggested understanding of the role of Moses is valid, it is impossible to deny some form of competition between David and Moses; and there might have been those, who claimed that Moses was better than David after all. But it is then necessary to recall the last time Moses is mentioned by name in the Psalter, it is he who does something wrong, even if the people is to be blamed: "(The people) made (Moses') spirit bitter, and he spoke words that were rash" (Ps 106:33).

Furthermore, it is not convincing that the emphasis on the kingdom of Yahweh implies a rejection of the kingdom of David. On the contrary; the more effective God's kingdom is, the more the earthly divine king can act, especially if he keeps to the plans of God. Already from the second Psalm this becomes clear, and the rejection of the king in the last part of Ps 89 is not necessarily an annulment of the ideology of Ps 2 and other royal Psalms. On the contrary, the stronger Yahweh's kingdom, the better the chances of establishing and reestablishing David's kingdom. This does not happen in the fourth book of the Psalter, but in the last and fifth. In Ps 110 a statement about the divine birth of the king is repeated and the promise is given that the enemy will (again) be placed under his feet, and in Ps 132 the promises related to the covenant between Yahweh and his king are again taken up together with some terms of obedience, which are always connected with the relation to God.

So after all, the Psalter are not Moses' psalms, but the Psalms of David!

\section{THE PSALMS IN CHRISTIAN BIBLES}

The Bible is composed of the Old Testament and the New Testament as one book in Christian editions, and when read according to the holistic approach, this of course has put a new perspective on the Old Testament Books. Furthermore, many of the Christian Bibles contain seven books, the so-called Apocrypha, in

\footnotetext{
${ }^{20}$ I consciously avoided the term Enthronement Psalms from Mowinckel (1922), because it is so closely related to his cultic interpretation, which I don't wish to discuss here.

${ }^{21}$ Wilson (1985:215) summarises the answers given to the failure of the Davidic covenant in the fourth book: (1) YHWH is king; (2) He has been our "refuge" in the past, long before the monarchy existed (i e, in the Mosaic period); (3) He will continue to be our refuge now that the monarchy is gone; (4) Blessed are they that trust in him.
} 
addition to the books in the Hebrew Bible. Depending on the different translations, some of the books are shorter or longer than in the Hebrew Bible; as was previously mentioned there can be more Psalms in a Christian Bible than the 150 in the Hebrew Bible (see Jeppesen 2002). In the development from the Jewish Bible in Hebrew to the Christian Bible in many languages several changes occurred both in respect of the order of the Old Testament books and in the theological understanding thereof.

This development began with the Greek translations, especially the Septuagint, which originally was a translation for the Jews in the Diaspora, and at the same time was an attempt to introduce Jewish religion and philosophy in the Greek-speaking world. However, the further transmission of the Septuagint is related to the spreading of Christianity, and for this reason the Jews lost interest and confidence in it after a while. In the Christian use of the Old Testament books and the Apocrypha a shift in interest took place from the Law, taken as God's authoritative words to the Jewish people, to the Prophets, understood as a message bringing salvation to the whole world. In most modern Christian bibles, the twelve Minor Prophets are the last books in the Old Testament and prophecy has thus gained a conclusive importance as the link to the New Testament. ${ }^{22}$

In spite of these changes in viewpoints and disposition, the Psalter never lost its canonical significance; and soon became an important part of Christian spirituality. Together with the wisdom literature the Psalms found their place immediately after the historical books. At a later stage in the Bible's history the book of Job was moved to the place between the historical books and the wisdom and poetic books.

The importance which the Psalms gained in Christian tradition can only be fully understood if we appreciate what it entailed for the Psalms to be passed through the Greek translation. Therefore it is necessary, going on to the Psalter in the Christian canonical context, to point to a couple of matters in the

\footnotetext{
${ }^{22}$ The discussion regarding the right order of books is even more complicated in the case of the Septuagint than it is for the Hebrew Bible (see above). The three most important manuscripts Codex Vaticanus (early $4^{\text {th }}$ cent), Codex Sinaiticus (early $4^{\text {th }}$ cent), and Codex Alexandrinus do not follow the same outline, and this is one of reasons why modern printed editions of the Septuagint have the books in different order.
} 
Septuagint. ${ }^{23}$ The use of headings and stereotypes is more consistent in the Septuagint than in the Hebrew Bible; a consequence of this being for example that all the Psalms in the block of Psalm, Ps 111-119, open with a Hallelujah. ${ }^{24}$ Another example is that the procession Psalms, Ps 120-134, all share the same heading, "A song of ascension". This means that David is not mentioned in the headings of LXX-Ps 121; 123; 130, unlike in the Hebrew equivalents thereof.

The difference mentioned lastly pertains to the general tendency in the Septuagint to ascribe as many Psalms as possible to David. Almost all the Psalms which in the Hebrew Bible appear without heading, are presented as David-psalms in the Septuagint. All the Psalms in the first book, with the exception of Ps 1 and $2,{ }^{25}$ are now Psalms of David, and the Septuagint thus have more Psalms than in the Hebrew Bible which are related to episodes in David's life or related to cultic events he might have taken part in (see, e g, LXXPs 23; 26; 28). In other words, the Psalter in the Septuagint is even more focussed on David than the Hebrew Psalter, ${ }^{26}$ and this has without doubt been of significance to the Christian, messianic and eschatological interpretation of the biblical message, inclusive of the understanding of the Psalter as prophecies about Jesus of Nazareth.

The extended understanding of the Psalms in the Septuagint as royal or messianic texts is underlined by a Ps 151 or rather a final supernumerary Psalm. In its heading it is stressed that this Psalm is a genuine psalm of David, which means that the last Septuagint psalm is an I-psalm by the person, who was

\footnotetext{
${ }^{23}$ For the purpose of the present discussion, the differences in the numbering of the psalms are treated as minor problems. But it underlines the fact that the Psalter is different in different traditions that the Hebrew Ps 9-10 are passed on as one Psalm in Greek and that the same is the case with the Hebrew Ps 114-115. On the other hand both Hebrew Ps 116 and Ps 147 are divided into two Psalms in the Septuagint.

${ }^{24}$ The Hallelujahs, which in the Septuagint open the LXX-Ps 113-117, are in the Hebrew Bible placed at the end of the previous Psalm. BH-Ps 115 and 119 are not hallelujah psalms, but Ps 115 is in Greek part of the previous psalm, and the voluminous wisdom psalm Ps 119 has its own introductory hallelujah as LXX-Ps 118.

${ }^{25}$ Of course BH-Ps 10 , which is part of LXX-Ps 9, does not have its own heading.

${ }^{26}$ Schaper (1995:107) terms it "A network of messianic texts" and deals with the Messiahredaction of the Septuagint Psalter (Schaper 1995:72-126). A similar tendency to focus on David is found in the psalm scroll 11QPs ${ }^{a}$ (see, e g, Vanderkam 1994:135-139).
} 
supposed to be the author of the whole collection. David's election and anointment in preference of his older brothers form the theme of Ps 151, and the Psalm concludes with a poetic report about the killing of Goliath. ${ }^{27}$

In spite of minor differences between the two editions of the Psalter, as was demonstrated above, it is possible to find precisely the same line of thoughts in both the Greek and Hebrew text, including the rejection of the anointed and the re-proclamation of the promises to him. As the rest of the Psalm, the final line of Ps 151 is David's own words: "I removed the shame from the Israelites" (Ps 151:7), and this may be understood as the final statement proclaiming that the messianic balance was again found. In a way it is strange that Ps 151 has not played a prominent role in western Christendom.

Another feature which has made the Psalms in Greek applicable to the early church is that they often have a stronger eschatological perspective than the Hebrew Vorlage. In this instance I shall restrict myself to mentioning two examples from the Septuagint, which illustrate this tendency. ${ }^{28}$ In Ps 1:5 it is said that "the wicked will not stand in the judgement", but in the Greek translation the verb is not "stand (firm)", but "stand up" in the sense of being resurrected, and the translation thus relates the text to the day of judgement. In Ps 46:9 the "desolations", Yahweh brought on the earth, are understood as "wonders", and in this way the destruction of the weapons in the following verse can be interpreted as the beginning of the messianic age.

These tendencies are probably not the result of the Christian adoption of the Hebrew text only; the way of thinking in these examples fits in with some ideas in contemporary Judaism, as expressed in for example the book of Daniel which is normally considered as the youngest Old Testament book. But the twist in the eschatological direction assisted in clearing the way for the liturgical use of the Psalms as expression for the Christian congregation's prayer and praise to God.

But before the Psalms became part of the spirituality of the western churches, they were translated into Latin. In the so-called Vulgate translation, the

${ }^{27}$ See more about Ps 151 and the Hebrew edition of the text from Qumran in Jeppesen (2002).

${ }^{28}$ More examples are to be found in Schaper (1995); the two examples are from 46-48; 52-53. 
Old Testament books probably follow the order of the Greek edition as it was known to the translator Jerome, which was not completely identical to what we know as the Septuagint. A chronological principle seems to have been important. Job was supposed to have predated David in history and as a consequence, the book of Job precedes that of the Psalter, and following the Psalter are those books attributed to David's son, Solomon, namely the Proverbs, Ecclesiastes, the Song of Songs and the apocryphal Wisdom of Solomon.

As was already mentioned, the Vulgate became the bible of the Western churches and especially the authorized version in the Roman tradition. When Luther, as the first in modern times to have produced a translation in a national language, German (1522-1534), he based it upon the Hebrew text, but he retained the same order of the books as he knew it from the Vulgate - except that he excluded the Apocrypha. This explains why the Psalter in the Luther Bible and indeed in other reformation bibles - is found between the book of Job and the Proverbs, followed by Ecclesiastes.

This short outline of the Bible's history serves as background for the fact that the Psalter is placed centrally in the Lutheran bible, which is considered by many in Northern Europe as their canon. In the Danish Old Testament I have on my desk, Ps 1 appears not far removed from its midpoint. The Psalter is surrounded by books belonging to the Wisdom genre which as noted above, is the least specific Jewish-Israelite part of the Old Testament. As proven earlier, the structure of the Psalter in itself supports the idea that the Psalms are not only to be sung by the Israelites, but by the whole world, and this idea is supported by the surrounding wisdom books. This fact, coupled with the Septuagint's underscoring of the eschatological and messianic perspective in the Psalter, have made the book of Psalms to be one of the most loved and used books in the Christian Old Testament canon.

\section{Works consulted}

Aurelius, E 1988. Der Fürbitter Israels: Eine Studie zum Mosebild im Alten Testament. Stockholm: Almqvist \& Wiksell. (CBAT 27.)

Beckwith, R 1985. The Old Testament canon of the New Testament church and its background in early Judaism. London: SPCK. 
Carlson, A 2000. Psaltarens prolog i Ps 1-2. SEA 65, 114-121.

Childs, B S 1979. Introduction to the Old Testament as scripture. Philadelphia, PA: Fortress.

Gunkel, H 1926. Die Psalmen. Göttingen: Vandenhoeck \& Ruprecht. (GHAT.)

Gunkel, H \& Begrich, J 1933. Einleitung in die Psalmen: Die Gattungen der religiösen Lyrik Israels, zu Ende geführt von Joachim Begrich. Göttingen: Vandenhoeck \& Ruprecht. (GHAT.)

Holt, E K \& Nielsen, K (eds) 2002. Dansk kommentar til Davids Salmer, I-III, Fredericksberg: Amis.

Howard, D M 1993. A contextual reading of Psalms 90-94, in McCann, J C (ed), The shape and the shaping of the Psalter, 108-117. Sheffield: Sheffield Academic Press. (JSOTSS 159.)

Jeppesen, K 1998. "Alle der ånder skal lovprise Herren!”, in Holt, E K (ed), Alle der ånder skal lovprise Herren! Det Gamle Testamente i tempel, synagoge og kirke, 13-32, Frederiksberg: Anis.

Jeppesen, K 2002. Psalm 151 in Greek, Hebrew and Danish, in Pedersen, K S, Jeppesen, K \& Kaplan, S, Psalm 151 in Ethiopian tradition in celebration of Dr Kirsten Stoffregen Pedersen's $70^{\text {th }}$ birthday, 17-23. Jerusalem: ETRFI e a.

Koch, K 1994. Der Psalter und seine Redaktionsgeschichte, in Seybold, K \& Zenger, E (eds), Neue Wege der Psalmenforschung. Freiburg Herder. (Herders Biblische Studien 1.)

Kraus, H-J1960. Psalmen, II. Neukirchen: Neukicherner Verlag. (BKAT 15/2.)

McCann, J C 1993. Books I-III and the editorial purpose of the Psalter, in McCann, J C (ed), The shape and the shaping of the Psalter. Sheffield: Sheffield Academic Press. (JSOTSS 159.)

McCann, J C (ed) 1993. The shape and the shaping of the Psalter. Sheffield: Sheffield Academic Press. (JSOTSS 159.)

Millard, M 1994. Die Komposition des Psalters: Ein formgeschichtliche Ansatz. Tübingen: Mohr. (FAT 9.)

Miller, P D 1993. The beginning of the Psalter, in McCann, J C (ed), The shape and the shaping of the Psalter, 83-92. Sheffield: Sheffield Academic Press. (JSOTSS 159.)

Mowinckel, S 1922. Psalmenstudien, II, Das Thronbesteigungsfest Jahwäs und der Ursprung der Eschatologie. Viden-skapsselskapets Skrifter II, Hist. Filos. Klasse 1921, No.2, Kristiania, Oslo. 
Mowinckel, S 1962. The Psalms in Israel's worship, I-II, Oxford: Blackwell.

Müller, M 1996. The first Bible of the church: A plea for the Septuagint. Sheffield: Sheffield Academic Press. (JSOTSS 206.)

Scaper, J 1995. Eschatology in the Greek Psalter, I. Tübingen: Mohr. (WUNT 76.)

Vanderkam, J C 1995. The dead sea scrolls today. Grand Rapids: Eerdmans.

Von Rad, G 1969. Theologie des Alten Testaments, Band 1: Die Theologie der geschichtlichen Überlieferungen Israels. München: Kaiser.

Westermann, C [1961-1962] 1964. Zur Sammlung des Psalters. Theologia Viatorum 8, 278-284, reprint in Forschung am alten Testament: Theologische Bücherei, 336343. Kaiser, München. (AT 24.)

Westermann, C 1964. Der 90. Psalm, in Calwer Predigthilfen, 47-56. Stuttgart. (AT 3.), reprint in Forschung am alten Testament: Theologische Bücherei, 344-350. München: Kaiser. (AT 24.)

Whybray, N H 1996. Reading the Psalms as a book. Sheffield: Sheffield Academic Press. (JSOTSS 222.)

Wilson, G H 1985. The editing of the Hebrew Psalter. Chico: Scholars Press. (SBL Dissertation Series 76,) 